\title{
HAK ANGKET DPR VS KEBERADAAN KPK RI DALAM SISTEM KETATANEGARAAN INDONESIA
}

\author{
Oleh Tomson Situmeang ${ }^{1}$ \\ Email: tomson.situmeang@uki.ac.id \\ Universitas Kristen Indonesia
}

\begin{abstract}
Indonesia is a country that is limited by the constitution, in accordance with the provisions of Article 1 paragraph (2) and (3) of the 1945 Constitution. What is carried out by the executive, legislative, and judicial institutions with different roles, functions and tasks that do not intervene with each other, but are interconnected and intersecting. For example, the DPR Questionnaire Rights to the KPK raises pros and cons, because there are those who think that the KPK cannot be submitted to a questionnaire, but there are those who think that the KPK can also be asked for a questionnaire by the DPR. Questionnaire rights are one of the rights owned by the DPR in carrying out the supervisory function by conducting an investigation of the implementation of a law and/or government policy relating to important, strategic, and broad impacts on the life of the community, nation and state that are allegedly contradictory with the law. KPK is a state institution formed based on the Law so that it is an Organ of Law, but that does not mean that the state institution has no legal or unconstitutional position. KPK is not explicitly mentioned in the 1945 Constitution, but both have constitutional importance in the constitutional system, and even the Constitutional Court states that the term state institution is not always mentioned in the 1945 Constitution, but also formed on the basis of orders from regulations under the constitution. Thus the existence of the KPK as an institution tasked with eradicating corruption is not outside the constitutional system, but instead is placed constitutionally and acknowledged its existence in the constitutional system as one of the state institutions.
\end{abstract}

\section{Keywords: DPR, Hak Angket, KPK}

\section{Pendahuluan}

Indonesia merupakan Negara Konstitusional atau Constitutional State, yaitu negara yang dibatasi oleh konstitusi ${ }^{2}$. Hal ini sejalan dengan ketentuan Pasal 1 ayat (3) Undang-Undang Dasar 1945 (“UUD 1945”) yang menyatakan: "Indonesia adalah Negara Hukum". Artinya penyelenggaraan negara yang dilakukan oleh lembaga eksekutif, lembaga legislatif, dan lembaga yudikatif harus berlandaskan konstitusi dan aturan hukum yang berlaku. Dimana eksekutif, legislatif maupun yudikatif mempunyai peran, fungsi dan tugas yang berbeda dan tidak saling mengintervensi. Hal ini sesuai dengan konsep trias politica yang dikemukakan oleh Montesque, yaitu konsep pembagian kekuasaan.

Akan tetapi, sesungguhnya konsep pembagian kekuasaan tersebut tidak secara murni dilakukan di

\footnotetext{
1 Dosen Tetap Fakultas Hukum Universitas Kristen Indonesia 2 Jimly Asshiddiqie, Pengantar Ilmu Hukum Tata Negara, (Jakarta: Rajawali Pers, Cet. II, 2010), h. 281.
}

Indonesia. Hal ini bisa kita lihat, lembaga Eksekutif, selain mempunyai tugas untuk menjalankan undangundang, juga turut serta membuat undang-undang. Demikian halnya Legislatif, selain mempunyai tugas membuat undang-undang, juga mempunyai fungsi mengawasi kinerja eksekutif. Adapun Yudikatif memang seolah hanya menjalankan tugas mengawasi jalannya pemerintahan dan negara secara keseluruhan, di antaranya mengadili berbagai sengketa dan menguji undang-undang, tetapi juga ternyata membuat berbagai ketentuan peraturan yang "mau tak mau" berlaku secara umum bagi pihak yang berperkara di pengadilan, bahkan tak jarang Peraturan Mahkamah Agung menjadi acuan atau titik tolak dalam memutus perkara. Meskipun tidak dapat saling mengintervensi satu sama lain, akan tetapi jelas terlihat bahwa ketiga kekuasaan ini saling berhubungan dan bersinggungan bahkan sering menimbulkan polemik. Sebagai contoh: polemik "Hak Angket" oleh Dewan Perwakilan Rakyat (“DPR") selaku lembaga legislatif terhadap Komisi 
Pemberantasan Korupsi ("KPK"). Polemik terjadi karena adanya "pro kontra" tentang kedudukan KPK. Sebagian pihak menilai KPK bukan merupakan lembaga yang dapat diajukan "Hak Angket", namun ada pihak yang menilai KPK merupakan lembaga yang juga dapat diajukan "Hak Angket" oleh DPR.

Hak Angket adalah salah satu hak yang dimiliki oleh DPR dalam menjalankan fungsi pengawasan, dimana Hak Angket diatur dalam ketentuan UU Nomor 17 Tahun 2014 tentang MPR, DPR, DPD, dan DPRD ("UU MD3", yang baru-baru ini mengalami perubahan setelah sebelumnya telah diubah dengan UU Nomor 42 Tahun 2014). Hak Angket diatur dalam ketentuan Pasal $79^{3}$.

Penggunaan Hak Angket oleh DPR terhadap KPK bermula atas usulan beberapa anggota DPR dari Komisi III yang protes terhadap KPK terkait persidangan kasus $e$-KTP di Pengadilan Tindak Pidana Korupsi Jakarta pada Pengadilan Negeri Jakarta Pusat. Dalam persidangan kasus e-KTP, Miryam S. Haryani yang merupakan politisi dari Partai Hanura mencabut keterangannya yang ada dalam Berita Acara Pemeriksaan yang dilakukan oleh KPK dengan alasan pada saat pemeriksaan mendapat tekanan dari Penyidik KPK. Hal ini membuat Miryam S. Haryani ditetapkan sebagai Tersangka oleh KPK dengan tuduhan "memberikan keterangan palsu dalam kasus $e-K T P$ ".

Atas pengakuan dari Miryam S. Haryani tersebut, beberapa penyidik KPK dihadirkan dan dimintai keterangan dalam perkara $e-K T P$, yang justru memberikan keterangan adanya pengakuan Miryam S. Haryani, yang mengaku mendapat tekanan dari anggota DPR lainnya. Atas hal tersebut, Komisi III mendesak agar KPK membuka rekaman pemeriksaan terhadap Miryam S. Haryani, namun ditolak oleh KPK. Penolakan tersebut yang kemudian menjadi alasan anggota DPR untuk menggulirkan penggunaan Hak Angket oleh DPR. Penggunaan Hak Angket oleh DPR terhadap KPK kemudian menuai pro maupun kontra. Pihak yang kontra menilai langkah DPR menggunakan Hak Angket tidak terlepas dari adanya dugaan sejumlah anggota DPR menerima uang hasil korupsi dalam kasus $e-K T P$, yang menyatakan KPK bukan lembaga yang dapat diajukan "Hak Angket". Di

\footnotetext{
3 Pasal 79 ayat (3) UU MD3 menyatakan: "Hak Angket adalah hak DPR untuk melakukan penyelidikan terhadap pelaksanaan suatu undang-undang dan/atau kebijakan pemerintah yang ber- kaitan dengan hal penting, strategis, dan berdampak luas pada kehidupan bermasyarakat, berbangsa, dan bernegara yang didu- ga bertentangan dengan peraturan perundang-undangan"
}

pihak lainnya menilai KPK juga merupakan lembaga yang dapat diajukan "Hak Angket" oleh DPR.

\section{Permasalahan}

1. Bagaimana keberadaan hak angket DPR dalam sistem ketatanegaraan Indonesia?

2. Apa implikasi hak angket DPR terhadap kedudukan KPK dalam sistem ketatanegaraan Indonesia?

\section{Tujuan Penulisan}

1. Untuk dapat memahami keberadaan hak angket DPR dalam sistem ketatanegaraan Indonesia.

2. Untuk mengetahui implikasi hak angket DPR terhadap kedudukan KPK dalam sistem ketatanegaraan Indonesia.

\section{Sistem Kekuasaan}

Pada dasarnya negara merupakan organisasi kekuasaan.Kekuasaannegaramerupakankewenangan negara untuk mengatur seluruh rakyatnya untuk mencapai keadilan dan kemakmuran serta keteraturan. Dalam prakteknya, dimungkinkan terjadi pemusatan kekuasaan pada satu orang atau satu lembaga saja yang berpotensi melahirkan kekuasaan yang absolut atau otoriter. Untuk menghindari hal tersebut, perlu adanya pemisahan ataupun pembagian kekuasaan, sehingga terjadi kontrol dan keseimbangan. Istilah pemisahan kekuasaan (separation of powers) dan pembagian kekuasaan (divisions of power) adalah dua istilah yang memiliki pengertian berbeda satu sama lainnya ${ }^{4}$.

Pemisahan kekuasaan berarti kekuasaan negara itu terpisah-pisah dalam beberapa bagian, baik mengenai organ ataupun fungsinya. Dengan kata lain, lembaga legislatif, eksekutif dan yudikatif merupakan lembaga yang terpisah satu sama lainnya dan berdiri sendiri tanpa memerlukan koordinasi dan kerjasama. Pada pembagian kekuasaan, kekuasaan negara dibagi-bagi oleh lembaga legislatif, eksekutif dan yudikatif yang dalam pelaksanaan peran, fungsi dan tugasnya dimungkinkan adanya saling koordinasi atau kerjasama. Sistem pembagian kekuasaan ini yang banyak dianut oleh negara-negara di dunia, salah satunya oleh Indonesia.

Pada prinsipnya, konstitusi suatu negara merupakan pencatatan pembagian kekuasaan di dalam

\footnotetext{
${ }^{4}$ Mohammad Kusnardi dan Hermaily Ibrahim, Pengantar Hukum Tata Negara, (1983), h. 140.
} 
suatu negara. Pembagian kekuasaan menunjukkan perbedaan antara fungsi pemerintahan yang bersifat legislatif, eksekutif, dan yudikatif, yang dikenal dengan istilah Trias Politika ${ }^{5}$. Trias Politika menyatakan kekuasaan negara terdiri atas tiga macam kekuasaan, yaitu: kekuasaan legislatif atau kekuasaan membuat Undang-Undang (rule making function); dan kekuasaan eksekutif atau kekuasaan melaksanakan Undang-Undang (rule application function); serta kekuasaan yudikatif atau kekuasaan mengadili atas pelanggaran Undang-Undang (rule adjudication function). Trias politika adalah suatu prinsip normatif yang menyatakan bahwa kekuasaan-kekuasaan (function) ini sebaiknya tidak diserahkan kepada orang yang sama untuk mencegah penyalahgunaan kekuasaan oleh pihak yang berkuasa ${ }^{6}$.

\section{Kekuasaan Legislatif dan Hak Angket}

Kekuasaan Legislatif adalah kekuasaan untuk membentuk undang-undang yang dipegang oleh $\mathrm{DPR}^{7}$. Undang-undang dibuat bertujuan agar kehidupan masyarakat seimbang dan mengurangi terjadinya konflik, dimana yang bertugas untuk melaksanakan undang-undang tersebut adalah eksekutif. Legislatif juga mempunyai fungsi untuk mengontrol dan mengawasi, apakah undang-undang sudah dilaksanakan atau tidak? Meskipun apabila pelaksanaan undang-undang melenceng, maka yang mengadili adalah yudikatif. Meski demikian, legislatif memiliki beberapa fungsi, yaitu: fungsi legislasi, fungsi anggaran dan fungsi pengawasan ${ }^{8}$. Fungsi pengawasan adalah untuk mengawasi pelaksanaan undang-undang dan/atau kebijakan pemerintah yang berkaitan dengan hal penting, strategis, dan berdampak luas pada kehidupan bermasyarakat, berbangsa, dan bernegara yang diduga bertentangan dengan peraturan perundang-undangan. Pengawasan dilakukan melalui sidang panitia dan melalui hakhak kontrol yang khusus, antara lain hak bertanya, hak interpelasi, hak angket dan hak menyatakan pendapat ${ }^{9}$, sebagaimana diatur dalam ketentuan Pasal 20A ayat (2) dan ayat (3) UUD 1945.

\footnotetext{
${ }^{4}$ Mohammad Kusnardi dan Hermaily Ibrahim, Pengantar Hukum Tata Negara, (1983), h. 140.

${ }^{5}$ Miriam Budiardjo, Dasar-Dasar Ilmu Politik, (Jakarta: Gramedia Pustaka Utama, 2005), h. 152.

${ }^{6}$ Ibid, h. 281-282.

${ }^{7}$ Pasal 20 ayat (1) UUD 1945, menyatakan: "Dewan Perwakilan Rakyat memegang kekuasaan membentuk Undang-Undang".

${ }^{8}$ Pasal 20A UUD 1945 ayat(1), menyatakan: "Dewan Perwakilan Rakyat memiliki fungsi legislasi, fungsi anggaran, dan fungsi pengawasan".

${ }^{9}$ http://www.dpr.go.id/tentang/hak-dpr
}

Hak angket DPR adalah hak DPR untuk melakukan penyelidikan terhadap pelaksanaan suatuundang-undangdan/ataukebijakanpemerintah yang berkaitan dengan hal penting, strategis, dan berdampak luas pada kehidupan bermasyarakat, berbangsa, dan bernegara yang diduga bertentangan dengan peraturan perundang-undangan ${ }^{10}$.

Hak angket bukan sesuatu yang asing dalam sejarah ketatanegaraan Indonesia. Hak Angket pertama kali digunakan pada tahun 1950-an, ketika itu Ketua Dewan Pertimbangan Agung ("DPA") R. Margono Djojohadikusumo mengusulkan agar DPR menggunakan hak angket untuk menyelidiki untungrugi penggunaan devisa oleh pemerintah sesuai dengan UU Pengawasan Devisen Tahun 1940. Hak angket tersebut dilaksankan oleh 13 anggota, diketuai oleh Margono, namun sampai Kabinet hasil Pemilu 1955 terbentuk, hasil hak angket tersebut tidak jelas.

Pada saat ini, di Indonesia Hak angket oleh DPR dapat diajukan sehubungan dengan pelaksanaan tugas dan wewenang DPR sebagaimana ketentuan Pasal 73 ayat $(3)^{11}$ dan Pasal 74 ayat (3) serta ayat (4) ${ }^{12} \mathrm{UU}$ MD3. Sedangkan pengertian hak angket diatur dalam ketentuan Pasal 79 ayat (3) UU MD3. Namun rumusan tersebut dinilai oleh beberapa kalangan mengandung ketidakjelasan atau multitafsir, sehingga dianggap tidak memenuhi asas kepastian hukum sebagaimana dimaksud Pasal 28D ayat (1) UUD $1945^{13}$ yang

\footnotetext{
${ }^{10}$ Implementasi hak angket pertama kali diatur dalam UU Nomor 6 Tahun 1954 tentang Penetapan Hak Angket Dewan Perwaki- lan Rakyat, yang diatur pada Pasal 1 ayat (2), yang menyatakan: "Putusan untuk mengadakan angket diambil dalam suatu rapat terbuka Dewan Perwakilan Rakyat, yang diadakan sesudah usul itu dibicarakan dalam seksi atau seksi-seksi yang bersangkutan, dan putusan itu memuat perumusan yang teliti tentang hal yang akan diselidiki". Namun ketentuan tersebut telah dibatalkan oleh Mahkamah Konstitusi sebagaimana Putusan Nomor 8/PUUVIII/2010, dengan alasan merupakan produk hukum pada masa UUDS 1950, sehingga tidak sejalan dengan UUD 1945.

${ }^{11}$ Pasal 73 ayat (3) UU MD3, menyatakan: "dalam hal pejabat negara dan/atau pejabat pemerintah sebagaimana dimaksud pada ayat (2) tidak hadir memenuhi panggilan setelah dipanggil 3 (tiga) kali berturut-turut tanpa alasan yang sah, DPR dapat menggunakan hak interplasi, hak angket, hak menyatakan pendapat, atau hak anggota DPR mengajukan pertanyaan".

${ }^{12}$ Pasal 74 ayat (3) UU MD3, menyatakan: "setiap pejabat negara atau pejabat pemerintah yang mengabaikan rekomendasi DPR, $D P R$ dapat menggunakan hak interplasi, hak angket, atau hak menyatakan pendapat, atau anggota DPR dapat menggunakan hak mengajukan pertanyaan".

Pasal 74 ayat (4) UU MD3, menyatakan: "dalam hal pejabat negara atau pejabat pemerintah mengabaikan atau tidak melaksanakan rekomendasi DPR sebagaimana dimaksud pada ayat (1), DPR dapat menggunakan hak interplasi, hak angket, hak menyatakan pendapat, atau hak anggota DPR mengajukan pertanyaan".

${ }^{13}$ Pasal 28D ayat (1) UUD 1945, menyatakan: "setiap orang ber-hak atas pengakuan, jaminan, perlindungan, dan kepastian hu-kum yang adil serta perlakuan yang sama di hadapan hukum".
} 
berimplikasi timbulnya beberapa penafsiran berbeda, sehingga timbul anggapan dan tuduhan kekeliruan DPR dalam menggunakan hak angket terhadap KPK. Sementara DPR dan beberapa kalangan juga menafsirkan pasal tersebut dapat digunakan untuk 2 (dua) hal, yaitu:

\section{1. untuk melakukan penyelidikan terhadap pe-} laksanaan suatu undang-undang; dan/atau

2. untuk melakukan penyelidikan terhadapkebijakan pemerintah yang berkaitan dengan hal penting, strategis, dan berdampak luas pada kehidupan bermasyarakat, berbangsa, dan bernegara yang diduga bertentangan dengan peraturan perundangundangan.

Akan tetapi, banyak pihak beranggapan tindakan DPR tersebut merupakan langkah politik yang digunakan untuk melemahkan upaya pemberantasan korupsi oleh KPK. Beberapa pihak memaknai ketentuan Pasal 79 Ayat (3) UU MD3 telah memberi celah bagi DPR untuk menggunakan haknya, tidak hanya terhadap pemerintah sebagai lembaga eksekutif, tetapi semua lembaga negara pelaksana undang-undang ${ }^{14}$.

\section{Lembaga atau Unit Pemberantasan Korupsi di Indonesia}

KPK bukanlah lembaga atau unit pemberantasan korupsi pertama di Indonesia. Jauh sebelum KPK dibentuk, Indonesia pada masa orde lama, tercatat tiga kali membentuk lembaga pemberantasan korupsi. Pada tahun 1957, Presiden Soekarno membentuk Panitia Retooling Aparatur Negara (PARAN) berdasarkan Undang-Undang tentang Keadaan Bahaya, yang dipimpin oleh A.H. Nasution dan dibantu oleh M. Yamin dan Roeslan Abdulgani. PARAN bertugas menjaga transparansi pejabat dengan mengisi Formulir Daftar Kekayaan Pejabat Negara (DKPN). Namun keberadaan PARA berakhir tragis, selain karena para pejabat berdalih sebagai bawahan presiden, juga karena instabilitas pemerintahan dengan seringnya berganti kabinet. Keadaan tersebut tidak berlangsung lama, pada tahun 1963, presiden Soekarno melalui Keputusan Presiden Nomor 275 Tahun 1963 membentuk lembaga baru yang juga dipimpin oleh A.H. Nasution dan dibantu oleh Wiryono Prodjodikusumo. Lembaga baru ini dikenal dengan "Operasi Budhi", yang bertugas

dan berwenang menyeret para pelaku korupsi ke

\footnotetext{
${ }^{14} \mathrm{http}: / /$ nasional.kompas.com/read/2017/07/08/13554941/hakangket-terhadap-kpk-bisa-ditafsirkan-legal-tetapi-tidak-tepat.
}

pengadilan, dengan sasaran utama perusahaan negara serta lembaga negara yang dianggap rawan praktek korupsi dan kolusi ${ }^{15}$.

Nasib lembaga ini juga sama dengan PARAN, karena selain alasan politis, juga masalah prosedural menjadi penghambat lembaga tersebut untuk bekerja. Hanya saja Operasi Budhi masih berhasil menyelamatkan keuangan negara kurang lebih Rp.11Milyar. Kegagalan Operasi Budhi dan kegemasan presiden Soekarno akan lambannya pemberantasan korupsi membuat lembaga "operasi budhi” diganti dengan Komando Tertinggi Retooling Aparat Revolusi (KONTRAR), dimana presiden Soekarno langsung yang memimpin lembaga ini dengan dibantu oleh orang kepercayaannya, yaitu: Soebandrio dan Letjen Ahmad Yani. Namun sampai berakhirnya kepemimpinan presiden Soekarno, pemberantasan korupsi pada masa orde lama tidak menunjukkan perkembangan berarti.

Pada masa Orde Baru, pada pidato kenegaraan tanggal 16 Agustus 1967, presiden Soeharto mengkritik Orde Lama yang tidak mampu memberantas korupsi. Pidato tersebut seakan memberi harapan besar dalam pemberantasan korupsi apalagi diikuti dengan pembentukan Tim Pemberantasan Korupsi ("TPK"), yang dipimpin oleh Jaksa Agung. Akan tetapi, TPK dipertanyakan keseriusannya dalam pemberantasan korupsi, sehingga berujung pada kebijakan presiden Soeharto untuk menunjuk Komite 4 (Empat), beranggotakan tokoh-tokoh tua yang bersih dan berwibawa, yaitu Prof. Johanes, I. J. Kasimo, Mr. Wilopo, dan A. Tjokroaminoto. Komite 4 ini mempunyai tugas utama untuk membersihkan Departemen Agama, Bulog, CV Waringin, PT. Mantrust, Telkom, dan Pertamina. Namun hasil temuan Komite 4, sama sekali tidak digubris oleh pemerintah yang membuat posisi Komite 4 menjadi lemah. Ketika Sudomo diangkat sebagai Pangkopkamtib, dibentuklah Operasi Tertib dengan salah satu tugasnya memberatas korupsi. Operasi Tertib ini juga tidak berhasil memberantas korupsi karena adanya perselisihan pendapat mengenai metode pemberantasan korupsi yang bottom up atau top down yang semakin melemahkan pemberantasan korupsi, dan pada akhirnya Operasi Tertib ini pun hilang dengan makin menguatnya kedudukan "para koruptor" di masa Orde Baru ${ }^{16}$.

\footnotetext{
${ }^{15}$ Prinst Darwan, Pemberantasan Tindak Pidana Korupsi, (Bandung: Citra Aditya Bakti, 2002), h. 11.

${ }^{16}$ Ibid, h. 13 .
} 
Pada masa era reformasi, usaha pemberantasan korupsi dimulai dengan diterbitkannya Ketetapan MPR RI No. XI/MPR/1998 tentang Penyelenggaraan Negara yang Bersih dan Bebas Korupsi, Kolusi dan Nepotisme (TAP MPR XI/1998) yang memiliki materi muatan tentang pemberantasan dan pencegahan korupsi, kolusi dan nepotisme. Pasal 5 TAP MPR XI/1998 berbunyi "Ketentuan sebagaimana dimaksud dalam Ketetapan ini diatur lebih lanjut dengan Undang-Undang". Materi muatan TAPMPR XI/1998 sifatnya perlu tindakan lebih lanjut sesuai ketentuan Pasal 3 ayat (2) yang berbunyi "Pemeriksaan atas kekayaan sebagaimana dimaksud pada ayat (1) di atas dilakukan oleh satu lembaga yang dibentuk oleh Kepala Negara yang keanggotaannya terdiri dari pemerintah dan masyarakat". TAP MPR XI/1998 diikuti dengan dikeluarkannya UU No. 28 Tahun 1999 tentang Penyelenggaraan Negara yang Bersih dan Bebas dari Korupsi, Kolusi, dan Nepotisme (UU No. 28/1999) dan UU No. 31 Tahun 1999 tentang Pemberantasan Tindak Pidana Korupsi (UU Tipikor). Terbitnya UU No. 28/1999 diikuti dengan pembentukan berbagai komisi atau badan baru, salah satunya Komisi Pengawas Kekayaan Pejabat Negara (KPKPN). Pada masa presiden Abdurrahman Wahid, melalui PPNo. 19Tahun 2000 dibentuk Tim Gabungan Pemberantasan Tindak Pidana Korupsi (TGPTPK). Di tengah semangat memberantas korupsi, TGPTPK terpaksa dibubarkan karena adanya putusan Judicial Review oleh Mahkamah Agung yang membenturkan keberadaan TGPTPK dengan landasan Peraturan Pemerintah terhadap UU Tipikor.

Selanjutnya terbitlah Ketetapan MPR RI Nomor VIII/MPR/2001 tentang Rekomendasi Arah Kebijakan Pemberantasan dan Pencegahan Korupsi, Kolusi dan Nepotisme (TAP MPR VIII/2001), yang merupakan kelanjutan dari TAP MPR XI/1998 ${ }^{17}$ yang dengan tegas menugaskan Presiden dan Lembaga Tinggi Negara lainnya untuk melaksanakan Rekomendasi Arah Kebijakan tersebut ${ }^{18}$. Terdapat 7

\footnotetext{
${ }^{17}$ Hal ini sesuai dengan bunyi Pasal 1 Ketetapan MPR RI Nomor VIII/MPR/2001 yang menyatakan: "Rekomendasi Arah Kebijakan ini dimaksudkan untuk mempercepat dan lebih menjamin efektivitas pemberantasan korupsi, kolusi dan nepotisme sebagaimana diamanatkan dalam Ketetapan MPR RI Nomor XI/ MPR/1998 tentang Penyelenggaran Negara yang Bersih dan Bebas Korupsi, Kolusi dan Nepotisme serta berbagai peraturan perundang-undangan yang terkait'.

${ }^{18}$ Pasal 3 Ketetapan MPR RI Nomor VIII/MPR/2001 yang menyatakan: "Rekomendasi Arah Kebijakan ini ditujukan kepada Presiden RI dan lembaga-lembaga tinggi negara lainnya untuk dilaksanakan sesuai dengan peran, tugas dan fungsi masingmasing, dan dilaporkan pelaksanaannya pada Sidang Tahunan MPR RI'
}

(tujuh) poin Arah Kebijakan sebagaimana tertuang dalam ketentuan Pasal 2 TAP MPR VIII/2001. ${ }^{19}$

Materi muatan butir 4 dan 5 perlu tindak lanjut, baik berupa pencabutan atau mengganti/merevisi peraturan perundang-undangan terkait dengan korupsi, kolusi dan nepotisme. Materi muatan poin 6 dan 7 yang harus ditindaklanjuti dengan membuat Undang-Undang. Selain adanya TAPMPR VIII/2001, seiring berjalannya era reformasi muncul berbagai macam perubahan dalam sistem ketatanegaraan, khususnya perubahan UUD 1945. Salah satu hasil dari perubahan UUD 1945 adalah beralihnya supremasi Majelis Permusyawaratan Rakyat ("MPR") menjadi supremasi konstitusi, sehingga MPR bukan lagi lembaga tertinggi negara karena didudukkan sederajat dalam mekanisme checks and balances. Konstitusi diposisikan sebagai hukum tertinggi yang mengatur dan membatasi kekuasaan Lembaga-Lembaga Negara yang ada. Untuk menjawab tuntutan tersebut, Negara membentuk Lembaga Negara yang baru yang diharapkan lebih responsif dalam mengatasi persoalan aktual negara ${ }^{20}$. Menurut Jimly Asshidiqie, disebut "Lembaga Negara Bantu" dalam bentuk dewan, komisi, komite, badan, ataupun otorita karena masing-masing memiliki tugas dan wewenang. Beberapa ahli tetap mengelompokkan Lembaga Negara Bantu dalam lingkup eksekutif. Ada juga sarjana yang menempatkan Lembaga Negara Bantu sebagai cabang ke empat kekuasaan pemerintahan.

Kehadiran Lembaga Negara Bantu menjamur pasca perubahan UUD 1945. Lembaga Negara Bantu dibentuk dengan dasar hukum yang tidak seragam, karena ada yang dibentuk karena amanat UUD 1945 dan ada yang dibentuk berdasarkan undang- undang ataupun Keputusan Presiden. Salah satu Lembaga Negara Bantu yang dibentuk adalah KPK, berdasarkan UU No. 30 Tahun 2002 tentang Komisi Pemberantasan Tindak Pidana Korupsi ("UU KPK"), sebagai tindak lanjut atas Arah Rekomendasi TAP MPR VIII/2001.

\footnotetext{
${ }^{19}$ Pasal 2 Ketetapan MPR RI Nomor VIII/MPR/2001, berbunyi: Arah kebijakan pemberantasan korupsi, kolusi dan nepotisme adalah:

1. Mencabut, mengubah, atau mengganti semua peraturan perundang-undangan serta keputusan-keputusan penyelenggara negara yang berindikasi melindungi atau memungkinkan terjadinya korupsi, kolusi, dan nepotisme.

2. Merevisi semua peraturan perundang-undangan yang berkenaan dengan korupsi sehingga sinkron dan konsisten satu dengan yang lainnya.

3. Membentuk Undang-undang beserta peraturan pelaksanaannya untuk membantu percepatan dan efektivitas pelaksanaan pemberantasan dan pencegahan korupsi yang muatannya meliputi: a. Komisi Pemberantasan Tindak Pidana Korupsi; b. Perlindungan Saksi dan Korban; c. Kejahatan Terorganisasi; d. Kebebasan Mendapatkan Informasi; e. Etika Pemerintahan; f. Kejahatan Pencucian Uang; g. Ombudsman.

4. Perlu segera membentuk Undang-undang guna mencegah terjadinya perbuatan-perbuatan kolusi dan/atau nepotisme yang dapat mengakibatkan terjadinya tindak pidana korupsi.

${ }^{20}$ Op.Cit., Prinst Darwan, h. 16.
} 


\section{Kedudukan KPK dalam Sistem Ketatanegaraan}

Lembaga negara yang dibentuk oleh UUD 1945 merupakan Organ Konstitusi; sedangkan yang dibentuk berdasarkan Undang-Undang merupakan Organ Undang-Undang. Dalam kaitan ini, Romli Atmasasmita berpendapat, sistem ketatanegaraan tidak dapat diartikan hanya secara normatif (hanya dari sudut ketentuan konstitusi), tetapi juga dapat diartikan secara luas karena tidak semua lembaga negara diatur dalam konstitusi. Apabila suatu lembaga negara tidak ditempatkan di dalam UUD 1945, bukan berarti lembaga negara tersebut tidak mempunyai kedudukan hukum atau inkonstitusional, karena sifat konstitusional suatu lembaga dapat dilihat dari fungsinya dalam melaksanakan tugas dan wewenang atas nama negara.

Perubahan UUD 1945 telah memunculkan lembaga negara baru, dimana Lembaga Negara yang diatur dalam UUD 1945 sering disebut sebagai Lembaga Negara Utama, sedangkan yang dibentuk berdasarkanketentuanperaturanperundang-undangan di bawah UUD 1945 sering disebut sebagai Lembaga Negara Penunjang atau Lembaga Negara Bantu. Hal tersebut membuat konsep Trias Politika dianggap sudah tidak relevan lagi. Apalagi lembaga negara tidak mungkin menjalankan fungsinya secara terpisah, karena kenyataannya antar lembaga negara saling bersentuhan dan berkedudukan sederajat. Berbagai penafsiran muncul, ada penafsiran yang membagi Lembaga Negara menjadi Lembaga Negara Utama (state main organ), yang masih mengacu pada konsep Trias Politika dan Lembaga Negara Bantu (state auxiliary organ), yaitu merupakan lembaga-lembaga lain yang tidak termasuk kategori Lembaga Negara Utama (Argama, Rizky: 2007). Hal ini terjadi karena adanya tekanan internal berupa kuatnya reformasi politik, hukum, dan sistem kemasyarakatan secara politis dan hukum yang menyebabkan dekosentrasi kekuasaan negara dan reposisi atau restrukturisasi dalam sistem ketatanegaraan. Secara eksternal berupa fenomena gerakan arus global pasar bebas, demokratisasi, dan gerakan HAM Internasional ${ }^{21}$.

Jika memaknai ketentuan Pasal 24 ayat (3) UUD 1945, yang berbunyi: "badan-badan lain yang fungsinya berkaitan dengan kekuasaan kehakiman diatur dalam undang-undang", maka Kejaksaan Agung atau Kepolisian adalah merupakan lembaga yang diamanatkan oleh UUD 1945 karena fungsinya masih berkaitan dengan kekuasaan kehakiman, yaitu: fungsi penyelidikan, penyidikan, dan/atau penuntutan hanya saja secara teknis diatur dengan undang-undang.

\footnotetext{
${ }^{21}$ Refly Harun, Menjaga Denyut Konstitusi: Refleksi Satu Tahun Mahkamah Konstitusi, (Jakarta: Konstitusi Pers, 2010), h. 60-61
}

Demikianlah halnya dengan KPK, meskipun tidak secara eksplisit disebut dalam UUD 1945, tetapi sama-sama memiliki constitutional importance dalam sistem konstitusional berdasarkan UUD 1945. Meskipun ada yang berpendapat keberadaan KPK adalah ekstra konstitusional, bahkan ada pula yang berpendapat keberadaan KPK yang diatur dengan Undang-Undangmengacaukansistemketatanegaraan, dengan alasan secara teori ketatanegaraan ada 3 teori yang merumuskan bagaimana suatu lembaga negara diluar eksekutif, yudikatif, dan legislatif dibentuk, yaitu: separation of power yang berciri tidak menerima kehadiran lembaga-lembaga penunjang tersebut, sehingga bisa disimpulkan sebagai ekstra konstitusional dan separation of function yang berciri masih bisa menerima kahadirannya sepanjang berhubungan dengan fungsi eksekutif, legislatif, dan yudikatif serta check and balances yang berciri menerima sepenuhnya kehadiran lembaga penunjang lain, bukan berarti KPK lembaga yang inskonstitusional. Bahkan Mahkamah Konstitusi menyatakan istilah "Lembaga Negara" tidak selalu dimasukkan atau disebutkan dalam UUD 1945 atau yang dibentuk berdasarkan perintah konstitusi, tetapi juga ada lembaga negara lain yang dibentuk dengan dasar perintah dari peraturan di bawah konstitusi. Jimly Asshiddiqie menyatakan: berdasarkan "Teori Norma Sumber Legitimasi", alat-alat perlengkapan Negara dikelompokkan menurut bentuk norma hukum yang menjadi sumber atau pemberi kewenangan kepada lembaga yang terkait. Lembaga yang dibentuk berdasarkan undang-undang, dimana proses pemberian kewenangan kepada lembaga ini melibatkan peran DPR dan Presiden, sehingga dalam hal pembubaran atau perubahan bentuk dan kewenangan lembaga ini juga melibatkan DPR dan Presiden. Keberadaan KPK sebagai lembaga yang bertugas memberantas korupsi tidak berada di luar sistem ketatanegaraan, tetapi justru ditempatkan secara konstitusional dan diakui keberadaannya sebagai salah satu lembaga negara.

Hal ini dengan tegas disebutkan dalam ketentuan Pasal 3 UU KPK, menyatakan: "Komisi Pemberantasan Korupsi adalah lembaga negara yang dalam melaksanakan tugas dan wewenangnya bersifat independen dan bebas dari pengaruh kekuasaan manapun". Dalam penjelasan Pasal 3 tersebut disebutkan yang dimaksud dengan "kekuasaan manapun" adalah kekuatan yang dapat mempengaruhi tugas dan wewenang Komisi Pemberantasan Korupsi atau anggota Komisi secara individual dari pihak eksekutif, yudikatif, legislatif, pihak-pihak lain yang terkait dengan perkara tindak pidana korupsi, atau keadaan dan situasi ataupun dengan alasan apapun. Oleh karenanya KPK merupakan lembaga negara yang bersifat independen yang dalam 
Jurnal Hukum tô-râ, Volume 3 No. 2, Agustus 2017 
melaksanakan tugas dan wewenangnya bebas dari kekuasaan manapun, namun berkaitan dengan kekuasaan kehakiman, tetapi tidak berada di bawah kekuasaan kehakiman. Namun, walaupun bersifat independen dan bebas dari kekuasaan manapun, KPK tetap bergantung kepada kekuasaan eksekutif dan legislatif dalam kaitan dengan masalah keorganisasian dan memiliki hubungan khusus dengan kekuasaan yudikatif dalam hal penuntutan dan persidangan perkara tindak pidana korupsi.

\section{Kesimpulan dan Saran}

Hak Angket DPR sesungguhnya dapat dilakukan untuk 2 hal, yaitu (a) untuk melakukan penye- lidikan terhadap pelaksanaan suatu undang-undang yang dilaksanakan oleh setiap lembaga negara, termasuk oleh KPK; dan/atau (b) untuk melakukan penyelidikan terhadap kebijakan pemerintah yang berkaitan dengan hal penting, strategis, dan berdampak luas pada kehidupan bermasyarakat, berbangsa, dan bernegara yang diduga bertentangan dengan peraturan perundang-undangan.

KPK adalah lembaga negara yang bersifat independen yang masuk kategori Lembaga Negara Bantu (state auxiliary organ), sama halnya seperti Komisi Pemilihan Umum. Sifat independen lembaga KPK bukan berarti KPK tidak boleh diawasi oleh DPR, tetapi sifat independen tersebut berlaku dalam proses penyelidikan, penyidikan dan penuntutan perkara yang dilakukan. Pengawasan yang dilakukan oleh DPR melalui Hak Angket terhadap KPK adalah sebagai pengewajantahan pengawasan oleh rakyat melalui lembaga perwakilan. Selain itu, KPK tetap bergantung kepada kekuasaan eksekutif dan legislatif dalam kaitan dengan masalah keorga- nisasian dan memiliki hubungan khusus dengan kekuasaan yudikatif dalam hal penuntutan dan persidangan perkara tindak pidana korupsi.

DPR dalam melakukan Hak Angket terhadap lembaga tertentu, termasuk terhadap KPK, bukan karena satu hal atau satu kasus tertentu, akan tetapi harus secara menyeluruh atas dugaan pelanggaran pelaksanaan undang-undang oleh lembaga tertentu tersebut atau oleh KPK dan tentunya dengan mem- perhatikan momen waktu yang tepat. Jangan sampai terjadi karena benturan kepentingan atau ketika ada perselisihan. 


\section{Daftar Pustaka}

Buku

Miriam Budiardjo, Dasar-Dasar Ilmu Politik, Jakarta: Gramedia Pustaka Utama, 2005.

Mohammad Kusnardi dan Hermaily Ibrahim, Pengantar Hukum Tata Negara, 1983.

Jimly Asshiddiqie, Pengantar Ilmu Hukum Tata Negara, Jakarta: Rajawali Pers, Cet. II, 2010.

Prinst Darwan, Pemberantasan Tindak Pidana Korupsi, Bandung: Citra Aditya Bakti, 2002.

Refly Harun, Menjaga Denyut Konstitusi: Refleksi Satu Tahun Mahkamah Konstitusi, Jakarta: Konstitusi Pers, 2010.

\section{Peraturan Perundang-Undangan}

Undang-Undang Dasar Negara RI Tahun 1945. Undang-Undang Dasar Sementara Tahun 1950.

Ketetapan MPR RI Nomor XI/MPR/1998 tentang Penyelenggaran Negara yang Bersih dan Bebas Korupsi, Kolusi dan Nepotisme.

Ketetapan MPR RI Nomor VIII/MPR/2001 tentang Rekomendasi Arah Kebijakan Pemberantasan dan Pencegahan Korupsi, Kolusi dan Nepotisme.

UU tentang Pengawasan Devisen Tahun 1940.

UU No. 6 Tahun 1954 tentang Penetapan Hak Angket Dewan Perwakilan Rakyat.

UU No. 28 Tahun 1999 tentang Penyelenggaraan Negara yang Bersih dan Bebas dari Korupsi, Kolusi, dan Nepotisme.

UU No. 31 Tahun 1999 tentang Pemberantasan Tindak Pidana Korupsi

UU No. 20 Tahun 2001 tentang Perubahan Atas Undang-Undang Nomor 31 Tahun 1999 tentang Pemberantasan Tindak Pidana Korupsi.

UU No. 30 Tahun 2002 tentang Komisi Pemberantasan Tindak Pidana Korupsi.

UU No. 17 Tahun 2014 tentang Majelis Permusyawaratan Rakyat, Dewan Perwakilan Rakyat, Dewan Perwakilan Daerah, dan Dewan Perwakilan Rakyat Daerah.

UU No. 42 Tahun 2014 tentang Perubahan Atas Undang-Undang Nomor 17 Tahun 2014 tentang Majelis Permusyawaratan Rakyat, Dewan Perwakilan Rakyat, Dewan Perwakilan Daerah, dan Dewan Perwakilan Rakyat Daerah.

Peraturan Pemerintah Nomor 19 Tahun 2000.

Keputusan Presiden Nomor 275 Tahun 1963.

\section{Putusan}

Putusan Mahkamah Konstitusi RI Nomor 8/PUU- VIII/2010.

Putusan Mahkamah Konstitusi RI Nomor 36/PUU- XV/2017.

\section{Internet}

1. http://www.dpr.go.id/tentang/hak-dpr

2. http://nasional.kompas.com/read/2017/ 07/08/13554941/hak-angket-terhadap-kpk-bisaditafsirkan-legal-tetapi-tidak-tepat 